\title{
CHANGES IN RADIOGRAPHIC PARAMETERS AFTER MINIMALLY INVASIVE LUMBAR INTERBODY FUSION
}

\author{
ALTERAÇÕES DOS PARÂMETROS RADIOGRÁFICOS DEPOIS DE FUSÃO \\ INTERSOMÁTICA LOMBAR MINIMAMENTE INVASIVA
}

CAMBIOS EN LOS PARÁMETROS RADIOGRÁFICOS EN FUSIÓN

LUMBAR INTERSOMÁTICA MÍNIMAMENTE INVASIVA

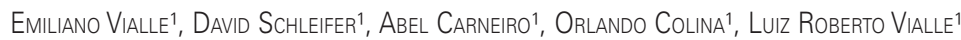

\begin{abstract}
Objective: This study aims to evaluate changes in lumbosacral parameters after minimally invasive lumbar interbody fusion. The secondary aim was to evaluate whether interbody cage shape (crescent shaped or rectangular) would influence the results. Method: Retrospective analysis of 70 patients who underwent one or two level lumbar interbody fusion through a minimally invasive posterolateral approach. This included midline preservation and unilateral facetectomy. Pre- and postoperative (three to six months postoperative) radiographs were used for measuring lumbar lordosis (LL), segmental lordosis (SL) at the level of interbody fusion, and sacral slope (SS). Further analyses divided the patients into Roussouly lumbar subgroups. Results: LL was significantly reduced after surgery $\left(59^{\circ}: 39^{\circ}, \mathrm{p}=0.001\right)$ as well as the SS $\left(33.8^{\circ}: 31.2^{\circ}, p=0.05\right)$. SL did not change significantly $(11.4: 11.06, p=0.85)$. There were no significant differences when comparing patients who received crescent shaped cage $(n=27)$ and rectangular cage $(n=43)$. Hypolordotic patients (Roussouly types 1 and 2$)$ had radiographic improvement in comparison to normolordotic and hyperlordotic groups (types 3 and 4). Conclusion: Minimally invasive lumbar interbody fusion caused reduction in lumbosacral parameters. Cage shape had no influence on the results.
\end{abstract}

Keywords: Lumbosacral region; Spine; Spondylosis; Spinal fusion; Postural balance; Minimally invasive surgical procedures.

\section{RESUMO}

Objetivo: Este estudo visa avaliar modificações dos parâmetros lombossacrais após fusão intersomática lombar minimamente invasiva. O objetivo secundário foi avaliar se o formato do dispositivo intersomático (meia lua ou retangular) influenciaria os resultados. Método: Análise retrospectiva de 70 pacientes submetidos à fusão intersomática lombar em um ou dois níveis por abordagem posterolateral minimamente invasiva, incluindo preservação da linha média e facetectomia unilateral. Radiografias pré e pós-operatórias (três a seis meses de pós-operatório) foram utilizadas para mensurar lordose lombar (LL), lordose segmentar (LS) no nível da fusão intersomática e inclinação sacral (IS). A avaliação ainda dividiu os pacientes nos subgrupos de Roussouly para lordose lombar. Resultados: A LL diminuiu significativamente após a cirurgia $\left(59^{\circ}: 39^{\circ}, p=0,001\right)$, assim como a IS $\left(33,8^{\circ}: 31,2^{\circ}, p=0,05\right)$. A LS não foi modificada significativamente $(11,4: 11,06, p=0,85)$. A comparação dos pacientes que receberam dispositivo em meia lua $(n=27)$ e retangular $(n=43)$ não mostrou diferenças significativas. Os pacientes hipolordóticos (tipos 1 e 2 de Roussouly) apresentaram melhora radiográfica em comparação com os grupos normolordótico e hiperlordótico (tipos 3 e 4). Conclusão: A fusão intersomática lombar minimamente invasiva levou a uma redução dos parâmetros lombossacrais. O formato do dispositivo intersomático não influenciou os resultados.

Descritores: Região lombossacral; Coluna vertebral; Espondilose, Fusão vertebral; Equilíbrio postural; Procedimentos cirúrgicos minimamente invasivos.

\section{RESUMEN}

Objetivo: El propósito de este estudio es evaluar las modificaciones en los parámetros lumbosacrales después de fusión lumbar mínimamente invasiva. El objetivo secundario es evaluar si los diferentes formatos de los dispositivos intersomáticos (en forma de media luna o rectangular) podría influir en los resultados. Método: Análisis retrospectivo de 70 pacientes sometidos a fusión intersomática lumbar en uno o dos niveles a través de un abordaje posterolateral mínimamente invasivo, incluyendo la preservación de la línea media y facetectomía unilateral. Radiografías pre y postoperatorias (tres y seis meses postoperatorios) fueron utilizadas para medir lordosis lumbar (LL), lordosis segmentaria (LS) a nivel de la fusión intersomática y la pendiente del sacro (PS). La evaluación también dividió a los pacientes en subgrupos lumbares de Roussouly. Resultados: La LL disminuyó significativamente después de la cirugía (59:39, $p=0,001)$, así como la PS $\left(33,8^{\circ}: 31,2^{\circ}, p=0,05\right)$. La LS no se modificó significativamente $(11,4: 11,06, p=0,85)$. No hubo diferencias significativas al comparar los pacientes que recibieron dispositivo en forma de media luna $(n=27)$ y rectangular $(n=43)$. Los pacientes hipolordóticos (tipos 1 y 2 de Roussouly presentaron mejoría radiológica en comparación con los grupos normolordótico y hiperlordótico (tipos 3 y 4). Conclusión: La fusión intersomática mínimamente invasiva causó una disminución de los parámetros lumbosacrales. El formato de los dispositivos intersomáticos no influyó en los resultados

Descriptores: Región lumbosacra, Columna vertebral, Espondilosis, Fusión vertebral, Balance postural, Procedimientos quirúrgicos mínimamente invasivos.

1. Pontifícia Universidade Católica do Paraná, Spine Surgery Group, Department of Orthopedics, Hospital Universitário Cajuru Hospital, Curitiba, PR, Brazil 


\section{INTRODUCTION}

Interbody fusion has become a common adjunct to posterior/ posterolateral fusion in lumbar degenerative pathology. Its use has long been established in the literature, advocating better fusion rates and improvement in lumbar sagittal alignment when compared to posterolateral fusion alone. 1,2 $^{2}$

Posterior interbody fusion has the advantages that it uses the same approach as that used for decompression and instrumentation, and the natural evolution of the technique has led to the widespread use of transforaminal unilateral interbody fusion, with reductions in surgical time, volume of bleeding, and dural sac retraction.

Currently, two different cage designs are commonly used: the bean shaped cage (BSC), which is positioned anteriorly in the intervertebral space, and rectangular/bullet shaped cages (RSC), which are positioned obliquely in the intervertebral space. Proponents of the BSC believe its anterior position allows for better recovery of lordosis, ${ }^{3}$ while proponents of the RSC state that there is no difference in the final results, and that there is no need for rotational maneuvers for anterior cage positioning, with little data available to support one shape over the other. ${ }^{4}$

The evolution of minimally invasive techniques has allowed surgeons to perform smaller decompressions for interbody fusion, with reduced muscle retraction, preservation of interspinous ligaments, shorter hospitalization, and faster recovery rates. Several studies have compared open to minimally invasive transforaminal lumbar interbody fusion (MITLIF) procedures, showing equivalent results in long-term follow up. ${ }^{5-9}$ The fact that more lamina are preserved, and that the contralateral facet is preserved, might have a bearing on its ability to regain lumbar lordosis after MITLIF, compared to open decompression with bilateral facetectomies. ${ }^{10}$

Another factor that has not been taken in consideration in decision-making for MITLIF is the type of lumbar lordosis, as different lumbar shapes might need a different surgical strategy.

This study evaluates the capacity of minimally invasive unilateral TLIF to improve lumbar lordosis, and to determine whether cage shape and preoperative lumbosacral alignment have an influence on final radiographic outcomes.

\section{MATERIAL AND METHODS}

This study is a retrospective analysis from a database of cases collected prospectively, from a single center, between 2010 and 2012. Informed consent was obtained from all patients, and the Institutional Review Board approved this study. (089852/2013).

The group consisted of 70 patients (37 male, 33 female, mean age 43 years) who underwent one or two level posterior lumbosacral fusion with unilateral interbody support using a minimally invasive, muscle-splitting approach. The surgical strategy consisted of midline and paravertebral muscle preservation, and unilateral facetectomy for decompression and cage insertion, followed by bilateral pedicle screw instrumentation.

Diagnosis included degenerative spondylolisthesis (19 cases) and symptomatic disc degeneration with or without lumbar stenosis (51 cases), which would require fusion according to the institution's protocol. ${ }^{4}$

Patient's with degenerative scoliosis, previous surgeries of the lumbar spine, symptomatic hip arthritis, lower limb problems that could influence posture, and those unable to sign the informed consent for the use of their medical records, were not included in this study. Patients with posteriorly placed cages (posterior half of the vertebral body) were also excluded from the study. Regarding disc height, all patients had type 3 and 4 discs (Pfirrmann classification), as type 5 discs do not receive interbody fusion in our institution. ${ }^{4}$

The patients received two different shapes of interbody construct (RSC, 43 patients or BSC, 27 patients), according to surgeon's preference and experience. Interbody support was used at L4L5 level in 32 cases and at L5S1 in 28 cases, and in 10 cases, both levels received interbody support.

Radiographic measurements included segmental lordosis (SL), sacral slope (SS) and lumbar lordosis (LL), pre- and postoperatively with a minimum follow up of six months. The images were digitalized, and measurements performed using specific software (Surgimap, Nemaris Inc.). SL measurements were carried out to evaluate the effect of the cage on local segment lordosis, and calculated using the angle between the endplates adjacent to disc space. LL (i.e. between the superior endplate of L1 and the superior endplate of S1) and SS (measured between the superior endplate of S1 and horizontal line, parallel to the floor) in order to analyze the lumbopelvic response to the procedure.

Patient groups were also stratified according to Roussouly's classification for lumbar lordosis, and statistical comparison was between groups was carried out using the Student's t-Test for parametric data, with a level of statistical significance of $p<0.05$.

\section{RESULTS}

The data analysis showed no significant difference between pre- and postoperative SL, and the comparison between BSC and RSC did not show any significant differences in the SL, as shown in Table 1. LL and SS were significantly reduced after surgery in both BSC and RSC groups, without any significant difference between groups.

Further stratification by age group and sex showed no significant differences in comparison to the whole group - data that could generate a deviation in the statistical analysis. Women had higher preoperative radiographic measurements, but the changes were similar to those in males (Table 2) in terms of maintenance of SL and reduction of $L L$ and $S S$.

The patients' stratification into Roussoully lumbar lordosis types showed a predominance of normolordotic (type 3) patients, over hypolordotic (types 1 and 2) and hyperlordotic (type 4) as shown in Table 3.

The comparison of radiographic data in these subgroups showed no significant difference in SL, and a significant reduction of LL and SS

Table 1. Comparison between pre and postoperative lumbosacral parameters.

\begin{tabular}{c|c|c|c|c|c|c}
\hline & SL pre & SL post & $\mathbf{p}$ & LL pre & LL post & $\mathbf{p}$ \\
\hline All patients & 11.4 & 11.06 & 0.85 & 59 & 39 & 0.001 \\
\hline BSC & 12.1 & 10.7 & 0.2 & 49.5 & 41.7 & 0.01 \\
\hline RSC & 11.3 & 11.8 & 0.3 & 50.4 & 43.7 & 0.009 \\
\hline & SS pre & SS post & $\mathbf{p}$ & & & \\
\hline All patients & 33.8 & 31.2 & 0.05 & & & \\
\hline BSC & 33.9 & 29.8 & 0.04 & & & \\
\hline RSC & 34.8 & 32.3 & 0.1 & & & \\
\hline
\end{tabular}

$\mathrm{SL}$ pre $=$ preoperative segmental lordosis; $\mathrm{SL}$ post $=$ postoperative segmental lordosis; $p=$ statistical significance; $L L$ pre = preoperative lumbar lordosis; $L L$ post= postoperative lumbar lordosis; $B S C=$ bean shaped cage; $\mathrm{RSC}=$ rectangular shaped cage; $\mathrm{p}=$ statistical diference.

Table 2. Comparison between male and female patients.

\begin{tabular}{c|c|c|c|c|c|c}
\hline & LS pre- & LS post- & $\mathbf{p}$ & LL pre- & LL post- & $\mathbf{P}$ \\
\hline Female & 12.7 & 12.2 & 0.4 & 52.5 & 43.2 & 0.003 \\
\hline Male & 11 & 10 & 0.4 & 48.3 & 42.7 & 0.02 \\
\hline & SS pre & SS post- & $\mathbf{P}$ & & & \\
\hline Female & 36.2 & 33.1 & 0.08 & & & \\
\hline Male & 33.2 & 29.8 & 0.05 & & & \\
\hline
\end{tabular}

$\mathrm{SL}$ pre = preoperative segmental lordosis; SL post = postoperative segmental lordosis; $p=$ statistica significance; LL pre= preoperative lumbar lordosis; LL post= postoperative lumbar lordosis.

Table 3. Stratification according to lordosis type

\begin{tabular}{c|c|c|c|c}
\hline Lordosis & $\mathbf{N}$ & $\mathbf{F}$ & $\mathbf{M}$ & Mean age \\
\hline 1 & 12 & 3 & 9 & 45 \\
\hline 2 & 17 & 7 & 10 & 43.3 \\
\hline 3 & 35 & 18 & 17 & 43 \\
\hline 4 & 6 & 4 & 2 & 40.6 \\
\hline Total & 70 & & & \\
\hline
\end{tabular}

$\mathrm{N}=$ number of patients; $\mathrm{F}=$ female; $\mathrm{M}=$ male. 
in the normolordotic group (type 3). The only subgroup that showed some improvement in the postoperative measurements was type 2 , with SS changes approaching the level of statistical significance $(p=0.05)$. (Table 4)

Table 4. Lumbosacral values according to lordosis type

\begin{tabular}{c|c|c|c|c|c|c|c|c|c}
\hline Lordosis type & $\begin{array}{c}\text { SL } \\
\text { Pre- }\end{array}$ & $\begin{array}{c}\text { SL } \\
\text { post- }\end{array}$ & $\mathbf{p}$ & $\begin{array}{c}\text { LL } \\
\text { Pre- }\end{array}$ & $\begin{array}{c}\text { LL } \\
\text { Post- }\end{array}$ & $\mathbf{P}$ & $\begin{array}{c}\text { SS } \\
\text { Pre- }\end{array}$ & $\begin{array}{c}\text { SS } \\
\text { post- }\end{array}$ & $\mathbf{P}$ \\
\hline 1 & 11.58 & 11.16 & 0.42 & 44.90 & 38.85 & 0.09 & 29.25 & 26.58 & 0.09 \\
\hline 2 & 11.23 & 11.52 & 0.44 & 37 & 35.75 & 0.36 & 24.47 & 28.52 & 0.05 \\
\hline 3 & 11.94 & 11 & 0.29 & 56.05 & 44.96 & $<0.001$ & 39.94 & 33.48 & 0.0001 \\
\hline 4 & 11.75 & 13.66 & 0.27 & 64.2 & 57.16 & 0.16 & 42.8 & 37.16 & 0.23 \\
\hline
\end{tabular}

$\mathrm{SL}$ pre = preoperative segmental lordosis; SL post = postoperative segmental lordosis; $p=$ statistical significance; LL pre= preoperative lumbar lordosis; LL post= postoperative lumbar lordosis; $p=$ statistical difference.

\section{DISCUSSION}

Interbody cages are an important adjunct to instrumented fusion for decreasing stresses on the posterior implants, allowing for increased fusion rates and improvement of lordosis. Although anteriorly inserted cages allow for better correction, due to lager cage shape and improved discectomy, posterior cages have the advantage of being part of a one-step procedure, meaning posterior instrumentation and decompression. ${ }^{11,12}$

The evolution of posterior interbody fusion led to the popularization of unilaterally placed cages (TLIF), which have been adapted for minimally invasive procedures. These changes enabled less aggressive procedures, with the preservation of muscular and ligamentous structures. ${ }^{8,9}$

One of the difficulties of MISTLIF is achieving adequate cage positioning, as most devices (BSC) need to be rotated inside the intervertebral disc space. In this study, the authors did not find any significant advantage of BSC over RSC, despite using all available maneuvers to increase lordosis (specially during patient positioning and compression between pedicle screws), in terms of an improvement in segmental lordosis or other sagittal radiographic measurements (LL and SS). RSC do not need to be manipulated inside the disc space, which can lead to faster cage insertion, reduced manipulation around the dorsal root and dural sac, and less exposure to radiation. Although some authors have shown advantages of BSC over RSC in open procedures, but these results have not been reproduced in MIS case series. (Table 5) 1 1-3,6-14

Sakaura et al, found that the laminar inclination angle has more effect in symptomatic adjacent segment pathology (ASP) after fusion surgery than the actual cage type or position. ${ }^{3}$

Other studies clearly show a difference in SL improvement when comparing open and MIS approaches, showing the importance of bilateral facetectomies, and perhaps a more aggressive discectomy when aiming for lordosis improvement. (Table 5)

\section{REFERENCES}

1. Gödde S, Fritsch E, Dienst M, Kohn D. Influence of cage geometry on sagittal alignment in instrumented posterior lumbar interbody fusion. Spine 2003;28:1693-9.

2. Lee KH, YueWM, YeoW, Soeharno H, Tan SB. Clinical and radiological outcomes of open versus minimally invasive transforaminal lumbar interbody fusion. Eur Spine J. 2012;21:2265-70.

3. Sakaura H, Yamashita T, Miwa T, Ohzono K, Ohwada T. Symptomatic adjacent segment pathology after posterior lumbar interbody fusion for adult low-grade isthmic spondylolisthesis. Glob Spine J. 2013:3·219-24.

4. Vialle E, Vialle L R. Estenose do Canal Vertebral Lombar. In: Martins DE, Puertas EB, Wajchenberg M, eds. , Clínica da Coluna Vertebral. São Paulo. Atheneu; 2014. p.93-104.

5. Goldstein CL, Macwan K, Sundararajan K, Rampersaud YR. Comparative outcomes of minimally invasive surgery for posterior lumbar fusion: a systematic review. Clin Orthop Relat Res. 2014 Jun;472(6):1727-37.

6. Hey HWD, Hee HT. Open and minimally invasive transforaminal lumbar interbody fusion: comparison of intermediate results and complications. Asian Spine J. 2015:9:185-93.

7. Jagannathan J, Sansur CA, Oskouian RJ, Fu KM, Shaffrey Cl. Radiographic restoration of lumbar alignment after transforaminal lumbar interbody fusion. Neurosurgery. 2009;64:955-64.

8. Sidhu GS, Henkelman E, Vaccaro AR, Albert TJ, Hilibrand A, Anderson DG, et al. Minimally invasive versus open posterior lumbar interbody fusion: a systematic review. Clin Orthop Relat Res. 2014;472: 1792-9.
Table 5. Relevant literature regarding lumbar lordosis and posterior interbody fusion.

\begin{tabular}{c|c|c|c|c}
\hline Author & Year & Open X MIS & Cage shape & SL \\
\hline Yson ${ }^{11}$ & 2012 & open & BSC & +7.2 \\
\hline Jagannathan $^{7}$ & 2009 & open & BSC & +17.4 \\
\hline Liang $^{13}$ & 2015 & Ml & BSC & +0.9 \\
\hline Godde $^{1}$ & 2003 & Open & BSC vs RSC & Favors BSC \\
\hline Lee $^{2}$ & 2012 & Open vs Ml & BSC & NRM \\
\hline Sakaura $^{3}$ & 2013 & Open & RSC & NRM \\
\hline Hey $^{6}$ & 2015 & Open vs Ml & BSC & Cage was shorter in Ml \\
\hline Sidhu $^{8}$ & 2014 & Open vs Ml & RSC & NRM \\
\hline Takahashi $^{9}$ & 2010 & Open & RSC & \\
\hline Villavicencio $^{10}$ & 2010 & Open vs Ml & BSC & NRM \\
\hline Fujimori & 2015 & Open & BSC & NRM \\
\hline Kim JT $^{14}$ & 2015 & Open & BSC vs RSC & 5.48vs3.37 \\
\hline
\end{tabular}

$\mathrm{Ml}=$ minimally invasive; $\mathrm{BSC}=$ bean shaped cage; $\mathrm{RSC}=$ rectangular shaped cage; $\mathrm{SL}=$ segmental lordosis (in millimeters ) NRM=no radiographic measurement.

Although sagittal imbalance was not the chief complaint of the patients in this study, it is possible that long-term results may be influenced by the small loss of lordosis and the need for compensatory mechanisms, leading to adjacent segment degeneration. ${ }^{15}$

The comparison between preoperative lordosis subtypes showed no significant difference. Patients with smaller preoperative lordosis (types 1 and 2) showed a tendency towards significant improvement of SL, in comparison to the normolordotic (type 3) and hyperlordotic (type 4) groups.

In patients with degenerative pathologies who are candidates for MISTLIF surgery, care should be taken in the preoperative evaluation regarding the need for lordosis improvement, so that the adequate procedure (open versus MIS) can be chosen. ${ }^{16}$

\section{CONCLUSIONS}

There were no differences between the two cage shapes regarding postoperative radiographic measurements. MISTLIF did not improve sagittal radiographic parameters in this group of patients. There were no significant differences between lordosis subtypes in the postoperative radiographic measurements.

All authors declare no potential conflict of interest concerning this article.
9. Takahashi H, Suguro T, Yokoyama Y, lida Y, Terashima F, Wada A. Effect of cage geometry on sagittal alignment after posterior lumbar interbody fusion for degenerative disc disease. J Orthop Surg. 2010:18:139-42.

10. Villavicencio AT, Burneikiene $\mathrm{S}$, Roeca CM, Nelson EL, Mason A. Minimally invasive versus open transforaminal lumbar interbody fusion. Surg Neurol Int. 2010;1:12.

11. Yson SC, Santos ERG, Sembrano JN, Polly DW. Segmental lumbar sagittal correction after bilateral transforaminal lumbar interbody fusion. J Neurosurg Spine. 2012:17:37-42.

12. Fujimori T, Le H, Schairer WW, Berven SH, Oamirani E, Hu SS. Does Transforaminal lumbar interbody fusion have advantages over posterolateral lumbar fusion for degenerative spondylolisthesis? Global Spine J. 2015: 5(2):102-9.

13. Liang $Y$, Shi W, Jiang $C$, Chen Z, Liu F, Feng Z, Jiang X. Clinical outcomes and sagittal alignment of single-level unilateral instrumented transforaminal lumbar interbody fusion with a 4 to 5-year follow-up. Eur Spine J. 2015;Apr 14.

14. Kim JT, Shin MH, Lee HJ, Choi DY. Restoration of lumbopelvic sagittal alignment and its maintenance following. Eur Spine J. 2015;Mar 25

15. Vialle EN, Vialle LRG, Vidigal A. Artrodesis Lumbar Circunferencial Minima Invasiva. Funcionalidad y Complicaciones. Acta Ortop Mex. 2010:24(2):95-9.

16. Vialle EN, Vialle LRG, Gusmao MS, Rangel TAM, Moron RC, Rocha S, et al. Discectomia lombar transforaminal: estudo qualitativo em cadáveres. Coluna/Columna. 2009;8:134-8. 